\title{
An Investigation on the Status Quo of the Cultural Character Competence of Pre-Service English Teachers from the Perspective of Core Competency
}

\author{
Jian $\mathrm{LI}^{1}$ \& Tingting LUAN ${ }^{2}$ \\ ${ }^{1}$ Foreign Language School, Yancheng Teachers' University, Jiangsu, China \\ ${ }^{2}$ Experimental School Attached to Soochow University, Jiangsu, China \\ Correspondence: Jian LI, Foreign Language School, Yancheng Teachers University, China. E-mail: \\ lijianyc@126.com
}

Received: June 2, 2021

Accepted: July 5, $2021 \quad$ Online Published: July 15, 2021

doi:10.5539/ells.v11n3p22

URL: https://doi.org/10.5539/ells.v11n3p22

\begin{abstract}
Since the promotion of the New Curriculum Standards, the teaching of English subjects has taken the development of students' core competency as the specific goal, and attached great importance to the cultivation of the four dimensions of students' language ability, cultural character, thinking quality and learning ability, among which cultural character has become a focus of recent researches on English teaching. Under the quality education and the educational concept of "people-oriented", in-service and pre-service English teachers should also have excellent cultural qualities so as to play the role of cultural disseminators. Thus, the present paper aims to understand the status quo of pre-service English teachers' cultural character competence through questionnaire surveys and interviews, and then analyze the root causes of this situation, and explore effective measures to improve the cultural character competence of pre-service English teachers.
\end{abstract}

Keywords: cultural character competence, core competency, pre-service English teachers

\section{Introduction}

It is not difficult to find that in recent years, researches abroad have been delving into cultural teaching step by step, mainly taking students and teachers as subjects of researches and exploring the cultivation of cultural character from the perspective of awareness, but lacking more thorough exploration in the specific measures to cultivating cultural character. According to Brooks (1986, p. 119), culture is not the same as geography, history or literature because of its property of individuality. Alan Prout (2004, p. 23) discusses the cultural character and the changing social of contemporary childhood in The Future of Childhood, which mainly deals with the students and academics in the field of childhood study and education. Moran (2009, p. 79) discovered that cultivating cultural awareness needs real-to-life communication environments, and communication-oriented learning is conducive to the comprehension of cultural awareness. Halliday (2011, p. 106) pointed out that the process of forming cultural character is complex. However, it is of necessity to learn cultural knowledge and understand the diversity of global cultures. He also found that the cultivation of cultural character is not only limited in schools, but also in the on- the-job training.

In China, the research on "cultural character" is much less, and was mostly carried out in the past fifteen years. Liu Qidi pointed out in "Cultural Curriculum Reform and Cultural Characters" (2006, p. 16) that the cultural curriculum reform aims to cultivate and mold one's own cultural character. The promotion and perfection of cultural character is a sign of the maturity and success of the curriculum reform. He also stated that cultural character is embodied in the handling of ancient and modern Sino-foreign cultural relations; a broader view of knowledge issues.

$\mathrm{Wu}$ Zongyuan pointed out the significance of inheriting cultural character in university education from the aspects of humanistic care, life value, and social responsibility in "The Pursuit of Character in University Culture" (2008, p. 18).

In "Cultural Character Concerning Knowledge" (2010, p. 18), Han Tingbin proposed that cultural character embodies the intrinsic value of knowledge, which is not absolute, mechanical or rigid. 
In "On the Cultural Character of English Curriculum" (2020, p. 49), Li Hongen believes that in view of the inseparable relationship between language and culture, curriculum and culture, the cultural character of English curriculum itself is significant, and she pointed out that the formation of English curriculum cultural character is based on practical experience and is bred in cultural atmosphere, and the innovation of it lies in its own responsibility.

Above all, there are two major shortcomings in related researches at home: first, concrete measures to reinforce cultural character are urgently needed. Second, current research on cultural character calls for more surveys that take pre-service teachers as subjects. Therefore, this present study tries to make an advancement in both of these two aspects so as to provide inspirations and references for similar researches.

\section{Research Design}

\subsection{Research Questions}

The research aims at exploring the status quo of the cultural character competence of pre-service English teachers, thus, the author mainly focuses on the following three questions:

(1) What is the current situation of the cultural character competence of pre-service English teachers?

(2) What are the main factors contributing to the status quo?

(3) How to improve the cultural character competence of pre-service English teachers?

\subsection{Research Subjects}

In this survey, the subjects of the questionnaire are students of two senior classes majoring in English teaching in Yancheng Teachers University, and the total number is 66 . These two classes are parallel classes: the pedagogy of the faculties, the teaching materials and the teaching content are basically the same. The classes are allocated according to the admission scores, which can illustrate that the students of the two classes are of the same level. Also, all the students have received enough professional knowledge through related courses and have gained teaching experience in internship. The interviewees are 4 students randomly selected from two classes.

\subsection{Research Instruments}

\subsubsection{Questionnaire}

The author applies questionnaire to investigate the overall current situation of the cultural character competence of pre-service English teachers. According to the definition provided in the New Curriculum Standards, the questions designed in the questionnaire involves aspects of "humanistic literacy" "cultural awareness" and "behavioral orientation". Besides, owing to the special subjects, some of the questions are based on "teaching implementation". For "humanistic literacy", some basic knowledge in terms of geography, climate, history, traditional customs and practices, literature, economy, etc. are included to test the answerers' cultivation of this aspect; for "cultural awareness", answerers are asked about their standpoints of some cultural events to investigate their cross-cultural cognition and attitudes; for "behavior orientation", some questions about the pre-service English teachers' cross-cultural communication ability are set; for "teaching implementation", there are several questions asking the answerers' cultural teaching experience. In detail, the author designed 20 questions about these four aspects, each of which is connected with 5 questions, some of which are objective, some subjective. The types of the questions include single choices, multiple choices, gap-fillings, matching and slider bars.

\subsubsection{Interview}

In order to more accurately look into the factors that influence pre-service English teachers' cultural character competence, the author randomly selected 4 pre-service teachers for interviews with a total of 3 questions. The interview has two purposes, apart from investigating the specific situation of the pre-service English teachers' cultural character competence, it also aims at finding out the defects of the pre-service English teacher's cultural character competence.

\subsection{Data Collection}

The author uses the data analysis function of the Wisdom Star questionnaire system to analyze the answers to the 20 questions. The analysis function can visually reflect the selected rate of each option of choice questions, the average value of the slider bar questions and integrate all the answers to the gap-filling.

\section{Results and Discussions}

This chapter is going to make analysis of the results of the questionnaire and the interview, which serves as the 
foundation for putting forward suggestions for the development of pre-service English teachers' cultural character competence.

\subsection{Results and Analysis of the Questionnaire}

Altogether there are 66 students being asked to receive the investigation, and the actual recovery number is 62 , and are all effective. More detailed information is shown as follows:

\subsubsection{Humanistic Literacy}

All the five questions set in this aspect are single choices with a right answer, they are concerned with the geographical and climatic patterns, important historical events, literary works, political and economic situations of English-speaking countries. According to the automatic analysis, their respective accuracy is $46.77 \%, 64.52 \%$, $72.58 \%, 56.45 \%$ and $60 \%$, with an average of $60.064 \%$, which reflects the answerers' general inadequate accumulation of the basic cultural knowledge about the English-speaking countries, in spite of their previous attendance of some related courses like Introduction to British and American Culture, British and American literature.

\subsubsection{Cultural Awareness}

With respect to the aspect of cultural awareness, the questions are set in terms of two dimensions: (1) answerers' opinions on different kinds of Sino-foreign cultural exchanges; (2) answerers' attitudes towards Sino-foreign cultural differences while making cross-cultural communication. And both these two dimensions can show a general picture of the answerers' cross-cultural cognition and attitudes.

According to the analysis system, $90.32 \%$ of the answerers feel positive towards the recent popularity of our traditional festivals such as Spring Festival, Mid-autumn Festival and their customs in foreign countries; 61.29\% of them hold positive attitudes towards the celebration of foreign festivals around them; $85.48 \%$ of them object to cultural plagiarism between countries; $88.71 \%$ of them are sensitive to cultural distributions and $90.32 \%$ advocate equal cultural communication. Judging from the analysis statistic above, the author can safely conclude that most of the answerers do not extremely opposed to foreign culture, instead, most of them are with an open and inclusive mind: on the one hand, they fully respect and understand foreign culture, on the other hand, they bear strong confidence of their own culture. Also, they hold positive attitudes towards cultural differences between China and foreign countries.

\subsubsection{Behavioral Orientation}

Questions set in this aspect are to investigate the students' ability of using English in the progress of cross-cultural communication and actions they take to improve their cultural character.

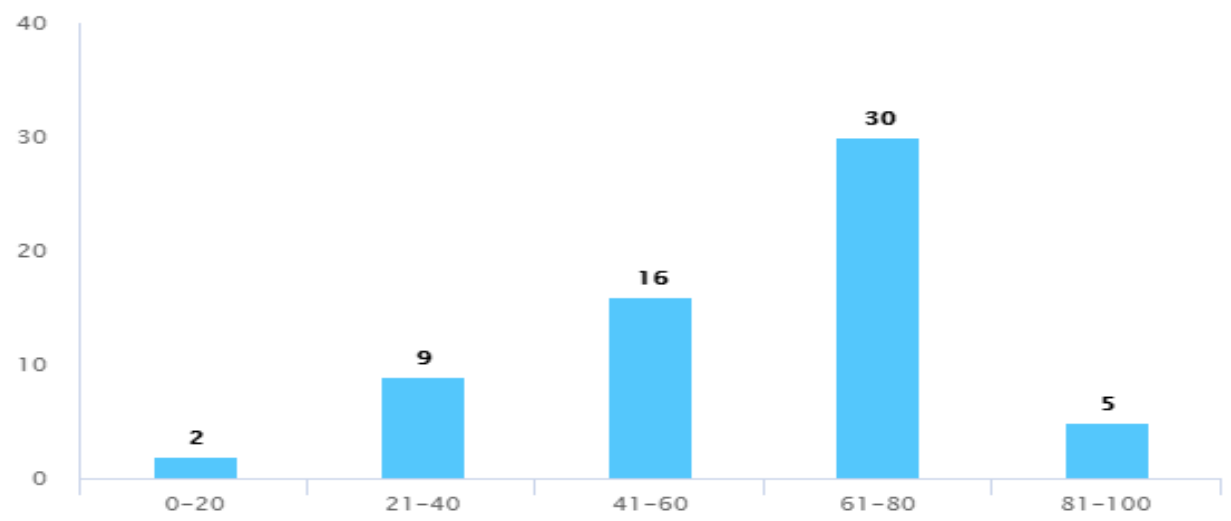

Figure 1. Self-evaluation slider bar

It is of great significance for English teachers to be capable of fluently introducing Chinese traditional culture in English, such as traditional festivals, delicacy, literature work, Peking opera, etc. According to the automatic analysis system, the self-evaluation slider bar, however, the average of the answerers' ability of this aspect is 59.21 on a scale from 0 to 100 , as can be seen in Figure 1 above, with $48.39 \%$ of them mark themselves $61-80$; $25.81 \%$ of them mark themselves $41-60 ; 14.52 \%$ mark $21-40 ; 8.06 \% 81-100$ and $3.23 \% 0-20$. To conclude, the ability of the answerers to make fluent cultural communication is far from enough, despite the important role this skill play in English teaching. 


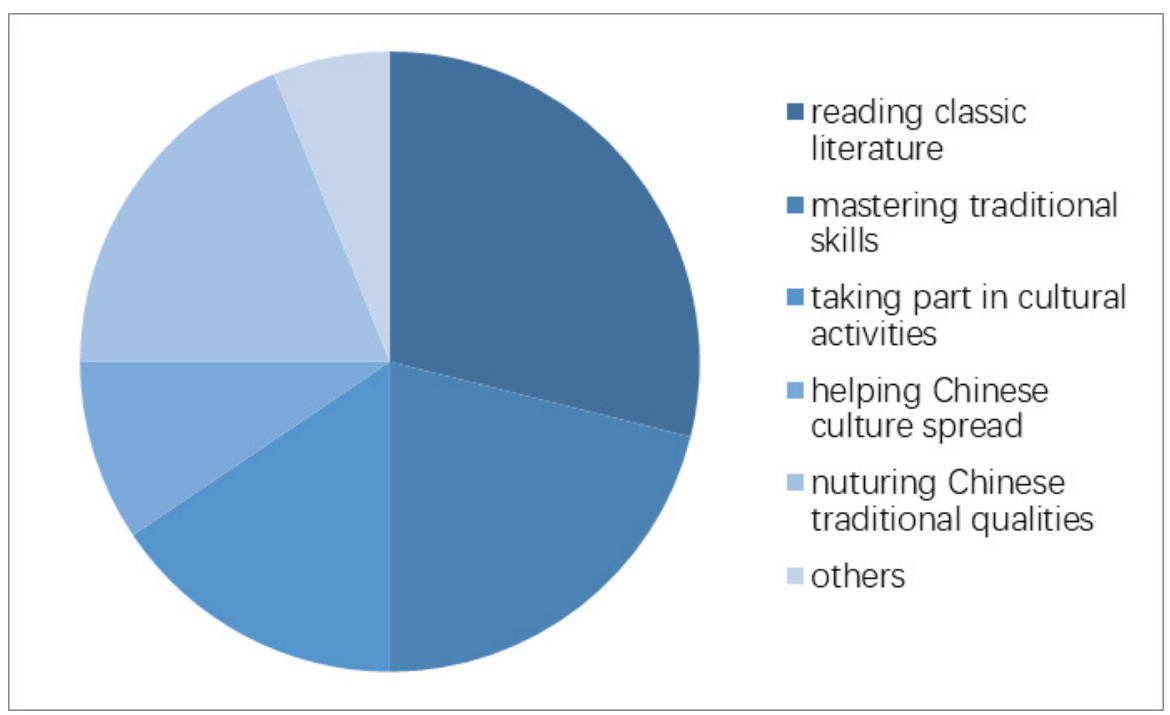

Figure 2. A Survey of carrying forward Chinese traditional culures

From the chart above, it is clear that most of the answerers find a common ground on the importance of carrying forward Chinese traditional culture, the detailed percentage of their practice on this act is as follows: $83.37 \%$ of them read Chinese classical literature work; $61.29 \%$ of them get trained to master traditional skills like calligraphy, weiqi, kungfu, etc; $45.16 \%$ of them take part in some related activities like poetry contests and traditional arts connoisseurship meeting; $27.42 \%$ of them help the traditional culture spread by introducing it to foreign people; $54.84 \%$ cultivate traditional positive qualities.

As for answering whether they follow the latest cultural trends of English-speaking countries or not, only 19 students listed out some cultural events or books they recently focus on, while the left 43 do not pay any attention on such things. What can be inferred from this is that the majority do not have motive to know current affairs about culture, and lack interests in and curiosity of the latest cultural trends.

\subsubsection{Teaching Implementation}

As for this dimension, questions are mainly about the students' cultural teaching experience during their internship experience or part-time of teaching English.

In terms of "How often do you involve traditional culture of English-speaking countries, such as festivals and their customs, practices and routines, values and beliefs, etc. in your teaching?", $45.16 \%$ of the answerers choose "often" and 54.84\% choose "seldom"; when being asked "How often do you talk with your students about current affairs and guide them to establish reasonable points of view?" $53.23 \%$ of them choose "often", $41.94 \%$ of them choose "seldom" and 4.84\% choose "never"; as for the question "How often do you compare and appreciate the similarities and differences between Chinese and foreign culture so as to encourage them to become more open and inclusive with cultural diversity?", $53.23 \%$ of them choose "often" and $46.77 \%$ choose "seldom".

When it comes to the multiple choices of what must be taught apart from the new words, sentence structures and grammatical knowledge, $83.87 \%$ of the answerers lay emphasis on the cultural background of the text; $74.1 \%$, central theme and Sino-western differences reflected by the text; $66.13 \%$, the capacity to comprehend the text; $69.35 \%$, the complement of the related materials; $61.29 \%$, guidance for after-class exploration.

According to the analysis, it is clear that great importance is attached to the indoctrination of Chinese traditional virtues apart from the emphasis on academic performance.

\subsection{Results and Discussions}

In order to get a more rounded and more deep assessment of what factors affect pre-service English teachers' cultural character competence, the author designed an interview targeting at four students majoring in English teaching in Yancheng Teachers University, which are represented by Interviewee A, B, C and D in the following analysis.

Question 1: As a pre-service English teacher, what is the role cultural teaching plays in English teaching in your 
opinion?

Interviewee A, B and D all expressed the idea that cultural teaching makes little sense to English teaching for that students needn't deal with problems in that aspect in exams. Interviewee $\mathrm{C}$ believed that cultural teaching can spice up the teaching progress and stimulate students' interests. Examples of the answers of Interviewee C and $\mathrm{D}$ are as follows:

Interviewee $\mathrm{C}$ : In my opinion, teaching cultural things is a useful tool for teaching a language in terms of adding some fun to the lesson so as to arouse students' interests.

Interviewee D: I don't think it's necessary to highlight cultural teaching since exams that students take rarely concern the field of cultural knowledge.

Question 2: What do you usually do to enhance your cultural literacy?

All the four interviewees seldom focus on the improvement of their cultural literacy, except for Interviewee D who always has English films and music at her fingertips. Examples of answers of Interviewee B and D are as follows:

Interviewee B: Actually, the author finds herself little interested in cultural things, so I almost do nothing to improve my cultural literacy.

Interviewee D: All I do to get my cultural literacy improved is watching English films and listening to English songs.

Question 3: What do you think needs to be improved in your culture related courses?

The four interviewees all pointed out their suggestions: Interviewee A thought that the teaching duration is not long enough for totally absorbing the knowledge. Interviewee $\mathrm{B}$ and $\mathrm{C}$ conveyed the desire to update their textbooks. And Interviewee D is satisfied with the courses she took. The following is the example of answers of Interviewee A and B:

Interviewee A: I don't think it is enough for us to take these courses for only half a semester because there are too much cultural knowledge to learn about, and in order to finish the teaching plan within the allotted time, we had no choice but to pick out a few units to learn.

Interviewee B: To be honest, the teaching materials are to some extent out of date. It's absolutely necessary to know "the past" of Britain and America, but we also like to get access to "the present" of these countries.

To sum up, neglect of the cultivation of cultural literacy, demerits coming up with exam-oriented education, unreasonable allocation of teaching hours and delay of updating the teaching materials are major factors hindering pre-service English teachers from improving their cultural character competence.

\section{Conclusion}

\subsection{Major Findings}

Through using the research method of the questionnaire, the question "what is the status quo of pre-service English teachers" has been answered, and the author comes up with the conclusion as follows:

(1) The entire humanistic literacy of the pre-service English teachers is at a low level in that their accumulation of basic cultural knowledge of English-speaking countries is far from enough.

(2) Most of the pre-service English teachers have established some at least proper cultural awareness, which can be explained by their respect and defend of Chinese culture and support of cross-cultural communication with an open mind.

(3) Pre-service English teachers are mainly exposed to their own culture and rarely take the initiative to learn about the culture of other countries and the differences between Chinese and foreign cultures. When it comes to capability, their abilities of using English is insufficient and their cross-cultural communication skills are limited.

(4) When it comes to their past teaching practice, pre-service English teachers have consciously integrated cultural teaching into their English teaching, but the frequency needs to be improved.

Through using the research method of the interview, the question "What are the major factors contributing to the status quo that has been found?" has been answered, and the author comes up with the conclusion as followed:

(1) Exam-oriented education has relatively low requirements for the inspection of cultural knowledge, resulting in most pre-service English teachers not paying enough attention to improving their own cultural qualities.

(2) Pre-service English teachers themselves lack interest in cultural aspects and do not actively cultivate cultural 
character.

(3) Insufficient hours of relevant professional courses have led to inadequate cultural teaching; teaching materials are outdated and the content is not new enough.

Judging from the conclusion above, the author brings forward several suggestions to get the cultural character competence of pre-service English teachers improved:

(1) Pre-service English teachers need to improve their own cultural literacy and strengthen their accumulation of cultural knowledge.

(2) Universities or teacher training institutions should add more emphasis on related cultural teaching of pre-service English teachers by increasing the teaching hour of cultural-related knowledge courses for pre-service English teachers, and attach importance to making the courses interesting as well as updating the teaching materials in time.

(3) The education department should energetically promote the concept of "cultural character" in all aspects, and appropriately set up cultural-related contents in the exams for students of elementary and middle schools.

\subsection{Limitations of the Research}

(1) The investigation just selects the students majoring in English teaching in the Yangcheng Teachers University as the subject, which might make the validity limited at some degree and the sample size of 62 was relatively small, so was that of the interview.

(2) The lack of enough literature to refer to is another deficiency of the research, especially foreign literature, thus the theoretical basis is not sufficient.

\section{Acknowledgements}

Funded by "Projects of Jiangsu Higher Education Reforms" (Grant Number: 2019JSJG323).

\section{References}

Alan, P. (2004). The Future of Childhood. Taylor and Francis. https://doi.org/10.4324/9780203323113

Brooks, N. (1986). Teaching in the foreign language classroom. Foreign Language Annals.

Halliday, A. (2011). Intercultural Communication and Ideology. London: SAGE Publications.

Han, T. B. (2010). On Cultural Characters of Knowledge. China's Higher Education, 20, 64.

Li, H. E. (2012). On the Cultural Characters of English Curriculums (p. 33). Chongqing: Southwest University,

Liu, Q. D. (2006). On Culture-style Curriculum Reforms and Cultural Characters-Practice of Curriculum Cultures. Current Education Science, 16, 5-19.

Moran, R. (2009). Cultural Teaching. Beijing: Foreign Language Teaching and Research Press.

Wu, Z. Y. (2008). The Character Pursuit of University Cultures. China's Adult Education, 16, 18-19.

\section{Copyrights}

Copyright for this article is retained by the author, with first publication rights granted to the journal.

This is an open-access article distributed under the terms and conditions of the Creative Commons Attribution license (http://creativecommons.org/licenses/by/4.0/). 